\title{
High rates of multi-drug resistant gram- negative organisms associated with surgical site infections in a teaching hospital in Ghana
}

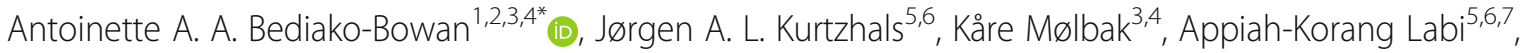 \\ Enid Owusu ${ }^{8}$ and Mercy J. Newman ${ }^{9}$
}

\begin{abstract}
Background: There is limited data to guide the prevention and management of surgical site infections (SSI) in lowand middle-income countries. We prospectively studied aetiological agents associated with SSI and their corresponding antibiotic susceptibility patterns in a tertiary hospital in Ghana.

Methods: As part of a cohort study carried out at the surgical department of the Korle Bu Teaching Hospital (KBTH) from July 2017 to April 2019, wound swabs were collected from patients diagnosed with SSI. Isolates cultured from the wound swabs were identified by MALDI TOF and susceptibility testing was conducted according to EUCAST 2020 guidelines. Clinical data were monitored prospectively.

Results: Of 4577 patients, 438 developed an SSI and 352 microbial isolates were cultured. Isolates were predominantly Gram negative $(286,81 \%)$, a pattern seen for all kinds of surgery and all wound classes. The most common species included Escherichia coli, Pseudomonas aeruginosa, Klebsiella pneumoniae, Staphylococcus aureus and Acinetobacter baumannii. The majority of organisms were multi-drug resistant including $86 \%$ of $E$. coli, $52 \%$ of $A$. baumannii and $86 \%$ of $K$. pneumoniae; and $65 \%(17 / 26)$ of the cefotaxime-resistant K. pneumoniae were extended spectrum $\beta$-lactamase producing. One of 139 E. coli, 15 of 49 P. aeruginosa, and 6 of 23 A. baumannii were meropenem resistant, but no clonal pattern was found. There was a 1\% (5/428) prevalence of methicillin-resistant $S$. aureus.

Conclusions: The predominance of Gram-negative organisms and the high level of multi-drug resistance indicate a need to re-evaluate antibiotic prophylaxis and treatment protocols in surgical practice in low- and middle-income countries.
\end{abstract}

Keywords: Multidrug resistant, Surgical site infection, Gram-negative organisms, ESBL, Ghana

\footnotetext{
* Correspondence: abediako-bowan@ug.edu.gh

'Department of Surgery, University of Ghana Medical School, University of

Ghana, P. O. Box 4356, Accra, Ghana

${ }^{2}$ Department of Surgery, Korle Bu Teaching Hospital, Accra, Ghana

Full list of author information is available at the end of the article
}

\section{$\triangle B M C$}

(c) The Author(s). 2020 Open Access This article is licensed under a Creative Commons Attribution 4.0 International License, which permits use, sharing, adaptation, distribution and reproduction in any medium or format, as long as you give appropriate credit to the original author(s) and the source, provide a link to the Creative Commons licence, and indicate if changes were made. The images or other third party material in this article are included in the article's Creative Commons licence, unless indicated otherwise in a credit line to the material. If material is not included in the article's Creative Commons licence and your intended use is not permitted by statutory regulation or exceeds the permitted use, you will need to obtain permission directly from the copyright holder. To view a copy of this licence, visit http://creativecommons.org/licenses/by/4.0/ The Creative Commons Public Domain Dedication waiver (http://creativecommons.org/publicdomain/zero/1.0/) applies to the data made available in this article, unless otherwise stated in a credit line to the data. 


\section{Background}

Surgical site infections (SSI) is a major type of healthcare associated infections (HCAI), forming as much as $33 \%$ of all HCAI in sub-Saharan Africa $[1,2]$. A major teaching hospital in Ghana also described an SSI incidence risk of $10 \%$ with an associated 9 extra days of stay and $\$ 1519$ excess cost to the institution per patient $[3,4]$.

The global spread of antibiotic resistance further compounds the problem of SSI. Infections caused by resistant bacteria lead to poor treatment outcomes. Major drivers of antimicrobial resistance in low- and middleincome countries include inappropriate prescription practices and poor infection control measures [5]. Thus, the prevalence of antibiotic use among surgical patients in sub-Saharan Africa is $24-73 \%$ [6], and the majority of these antibiotics are prescribed for prophylaxis and usually beyond the recommended 24-h period [7]. Reasons for this prolonged antibiotic use include a fear of infections due to poor infection control [8].

In Ghana, as in most low- and middle-income countries, antimicrobial treatment of wound infections is mainly empirical due to limited laboratory services in most health facilities and the costs to patients of culture and susceptibility testing, when available [9]. The selection of prophylactic antibiotic therapy is based on the operation site and the normal resident flora. Thus, empirical choice of antibiotics relies on knowledge of the susceptibility patterns of common local pathogens. Absence of this data precludes rational use of antibiotics for treatment and prevention of SSI.

In this study, we prospectively identified the aetiological agents of SSI at the surgical department of a tertiary hospital in Ghana, with emphasis on their antibiotic susceptibility patterns, and related to the patient characteristics.

\section{Methods}

Study site, patient recruitment and collection of samples Samples were collected as part of a cohort study at the surgical department of the Korle $\mathrm{Bu}$ Teaching Hospital from July 2017 to April 2019. The study design and results (for the period July 2017-December 2018) of the surveillance have been reported elsewhere [3]. All patients who underwent surgery in the unit were followed actively for the occurrence of SSI during admission and post-discharge for 30 days, and infection was defined according to Centers of Disease Control and Prevention (CDC) criteria [3, 10]. Wound contamination and SSI type were classified based on the CDC classification [10]. Implant surgery and surgery with wounds that could not be closed immediately were excluded.

Patients on admission had their change of dressing carried out on their bed in the wards. Post-discharge change of dressing was carried out in dressing rooms situated on each ward. Wound swabs were taken from consecutive patients diagnosed with SSI, either on admission or post discharge for microbiology analysis. The project staff had been trained to carefully collect exudate from the infected surgical site using sterile cottontipped applicators (Sterilin, U.K), which were transferred to the microbiology laboratory within an hour of sampling. Preliminary culture and susceptibility results were reported immediately to the physicians for management of patients. Isolates were then frozen at $-80{ }^{\circ} \mathrm{C}$ and transported to Copenhagen for confirmatory testing and additional analyses.

\section{Laboratory analyses}

Wound swabs were cultured on blood, chocolate and MacConkey agar plates. Isolates were identified using MALDI TOF Biotyper (Bruker Daltonics, Bremen, Germany). Here, susceptibility testing was conducted according to EUCAST 2020 guidelines [11]. The following discs were used; ampicillin $(10 \mu \mathrm{g})$, amoxicillinclavulanate $(20 / 10 \mu \mathrm{g})$, gentamicin $(10 \mu \mathrm{g})$, amikacin $(30 \mu \mathrm{g})$, ciprofloxacin $(5 \mu \mathrm{g})$, cefuroxime $(30 \mu \mathrm{g})$, ceftazidime $(10 \mu \mathrm{g})$, ceftriaxone $(30 \mu \mathrm{g})$, cefotaxime $(10 \mu \mathrm{g})$, tazobactam-piperracillin $(30 / 6 \mu \mathrm{g})$, meropenem $(10 \mu \mathrm{g})$, cefoxitin $(30 \mu \mathrm{g})$, erythromycin $(15 \mu \mathrm{g})$, clindamycin $(2 \mu \mathrm{g})$, sulphamethoxazole-trimethoprim $(25 \mu \mathrm{g})$, penicillin (1 unit), linezolid $(10 \mu \mathrm{g})$, tetracycline $(30 \mu \mathrm{g})$, (all from Oxoid Ltd., Basingstoke, United Kingdom (UK)). Isolates were categorized as "resistant" and "susceptible", including those "susceptible at increased exposure" also classified as "susceptible" [12]. E. coli ATCC 25922 and Staphylococcus aureus ATCC 25923 were used as controls for Gram negative and positive panels respectively. Klebsiella pneumoniae ATCC 700603 was used as quality control strains for ESBL screening.

Enterobacterales resistant to third generation cephalosporins were screened for production of extended spectrum beta lactamases (ESBL) using the double disc diffusion method [13]. Isolates with phenotypic resistance to meropenem were screened depending on the species. Pseudomonas spp. were screened for carbapenemases using GeneXpert (Xpert ${ }^{\circledR}$ Carba-R, Cepheid, France), Acinetobacter spp. were screened for OXA-23 using a rapid diagnostic test (OXA-23 K-SeT, Coris, Belgium), and Acinetobacter spp. and enterobacterales were screened for carbapenemases using NG-CARBA $5^{\circ}$ (Hardy Diagnostics, CA, USA). All Staphylococcus aureus isolates were screened for methicillin resistance using cefoxitin. Multidrug resistance (MDR) was defined as resistance to $\geq 1$ antibiotic in $\geq 3$ antibiotic groups [14].

\section{Data analysis}

For each bacterial agent, the percentage frequency of resistant isolates was determined. The resistance patterns 
of isolates of the same species were screened visually for possible clonal distribution. Distribution of bacterial types by clinical groups were compared by chi-square test and $p<0.05$ was considered significant. We used Stata /MP version 15.1 (Stata Corp., College Station, Tx, USA) for the analysis.

\section{Results}

\section{Demographic and patient characteristics}

A total of 4577 patients were included in the study. Of these, 438 (9.6\%) patients, developed an SSI. The SSI risk was $9.3 \%(376 / 4054)$ in the general surgical department, $26.5 \%(31 / 117)$ in the department of urology and $7.6 \%$ $(31 / 406)$ in paediatric surgery. The median age of the patients who developed an SSI was 45 years (interquartile range 31-60 years) and 239 (54\%) patients were female.

From $382(87 \%)$ of the 438 patients, a wound swab was taken for microbiological analysis. No wound swabs were taken in $13 \%(56 / 438)$ of the cases due to; surveillance team missing the opportunity to take a swab at change of wound dressing or at a relaparotomy for an SSI, missing the diagnosis of an SSI until the attention was drawn to the clinical signs and, wound swabs taken but accidentally sent to a private laboratory for analysis.

\section{Characteristics of surgical wounds}

The proportion of patients who developed an SSI was $5.2 \%(135 / 2589)$ for wounds classified as clean, $10.1 \%$ $(66 / 655)$ for a clean contaminated wound, $12.1 \%(104 /$ 859) for contaminated and $27.4 \%$ (130/475) for dirty wounds.

We found 352 isolates in 327 (86\%) of the 382 swabs. Most were monoculture, but two different species were cultured from each of 25 swabs. Isolates from clean wounds accounted for 29\% (103/352) of isolates, clean contaminated wounds for $14 \%$ (48), contaminated wounds for $26 \%$ (91), and dirty wounds for $31 \%$ (110) of isolated microorganisms.

\section{Aetiology of surgical site infections}

Gram-negative microorganisms constituted 81\% (286/352) of the isolates. The five most common microorganisms were Escherichia coli (139, 39\%), Pseudomonas aeruginosa (49, $14 \%)$, Klebsiella pneumoniae (35, 10\%), Staphylococcus aureus (33, 9\%) and Acinetobacter baumannii (23, 6\%), accounting for approximately $79 \%$ of the isolated organisms (Table 1).

Table 2 describes the pathogens by type of surgery. At least one isolate was found in 187 patients (11\%) of the 1646 gastrointestinal and other abdominal surgeries, in $12(8 \%)$ of 140 genitourinary and prostate surgeries, 38 (4\%) of 907 breast surgeries, 44 (5\%) of 866 hernia and scrotal surgeries, 25 (16\%) of 157 limb amputations, 9 (3\%) of 307 thyroid surgeries and 12 (2\%) of 554 other soft tissue surgeries. The ratio between Gram-negative and Gram-positive organisms differed by type of surgery (Table 3, $p=0.002$ ). For gastro-intestinal and genitourinary surgery, Staphylococcus spp. constituted $<16 \%$ of the isolates, whereas Staphylococcus spp. constituted > $25 \%$ of the isolates for hernia, breast, soft tissue and thyroid surgery. Despite this difference, Gram-negative organisms constituted $\geq 66 \%$ of isolates for all types of surgery and as much as $87 \%$ for gastro-intestinal surgery.

There was a difference between type of wound and the ratio between Gram-negative and Gram-positive organisms (Table 3), and S. aureus was only cultured from superficial SSI (Table 4). Conversely, all isolates from organ-space SSI were Gram negative. A much higher proportion of organ/space infections than other types of infections were not cultured, mostly due to the surveillance team missing the opportunity to take a wound swab during a relaparotomy to drain abscesses.

\section{Antimicrobial susceptibility patterns}

The majority of bacterial isolates were MDR, ranging from 23 to $86 \%$ for Proteus spp. and E. coli isolates, respectively (Table 1). Acquired resistance to commonly used antibiotics ranged from $1 \%$ to meropenem in $E$. coli to $95 \%$ to ampicillin, ciprofloxacin and trimethoprimsulphamethoxazole in E. coli (Fig. 1a).

Among E. coli and K. pneumoniae isolates, 60\% (82/ $139)$ and $74 \%(26 / 35)$, respectively were resistant to third generation cephalosporins. Sixty-one percent (50/82) and $65 \%(17 / 26)$ of the cefotaxime-resistant E. coli and K. pneumoniae, respectively were ESBL producing.

Meropenem resistance in this study was mainly found in Pseudomonas spp. (15 of 49 isolates) and Acinetobacter baumannii (6 of 23 isolates) (Table 1, Fig. 1b). Four $P$. aeruginosa isolates harboured the vim gene, encoding Verona integron-encoded metallo- $\beta$-lactamase. One $A$. baumannii expressed OXA-23. K. pneumoniae showed no resistance to meropenem (Fig. 1a).

Fifteen percent (5/33) of $S$. aureus isolates were methicillin resistant (MRSA). Overall, the MRSA prevalence was $1 \%(5 / 438)$ in the cultured wounds. Resistance of $S$. aureus against other antibiotics ranged from $6 \%$ to gentamycin and clindamycin to $42 \%$ to tetracycline. Among coagulase-negative staphylococci, the percentage resistance ranged from $23 \%$ to clindamycin to $81 \%$ to tetracycline. Neither $S$. aureus nor coagulase negative staphylococci showed resistance to linezolid (Fig. 1c).

The sensitivity pattern of the MDR organisms, including those for which specific resistance mechanisms such as ESBL or carbapenemases were detected, did not give any indication of an outbreak of one or more clones (data not shown). 
Table 1 Microbial isolates from infected surgical sites in a teaching hospital in Ghana

\begin{tabular}{|c|c|c|c|c|c|c|}
\hline Clinical isolates & $\mathbf{N}$ & $\%$ & $\begin{array}{l}\text { Number of isolates with } \\
\text { multidrug resistance (\%) }\end{array}$ & $\begin{array}{l}\text { Extended spectrum } \beta \text { - } \\
\text { lactamase-producing isolates } \\
(\%)\end{array}$ & $\begin{array}{l}\text { Meropenem } \\
\text { resistant isolates }^{\mathrm{a}} \\
(\%)\end{array}$ & $\begin{array}{l}\text { Number of isolates with } \\
\text { methicillin resistance (\%) }\end{array}$ \\
\hline Escherichia coli & 139 & 39.5 & $120(86 \%)$ & $50(36 \%)$ & $1(1 \%)$ & - \\
\hline Pseudomonas spp. & 49 & 13.9 & 17 (35\%) & - & $15(31 \%)$ & - \\
\hline $\begin{array}{l}\text { Klebsiella } \\
\text { pneumonia }\end{array}$ & 35 & 9.9 & $30(86 \%)$ & $17(48 \%)$ & 0 & - \\
\hline $\begin{array}{l}\text { Staphylococcus } \\
\text { aureus }\end{array}$ & 33 & 9.4 & $8(24 \%)$ & - & - & $5(15 \%)$ \\
\hline $\begin{array}{l}\text { Acinetobacter } \\
\text { baumannii }\end{array}$ & 23 & 6.5 & $12(52 \%)$ & - & $6(26 \%)$ & - \\
\hline Proteus spp. & 21 & 6.0 & $5(24 \%)$ & 0 & 0 & - \\
\hline $\begin{array}{l}\text { Staphylococcus } \\
\text { haemolyticus }\end{array}$ & 15 & 4.3 & $14(93 \%)$ & - & - & 0 \\
\hline $\begin{array}{l}\text { Staphylococcus } \\
\text { epidermidis }\end{array}$ & 11 & 3.1 & 10 (91\%) & - & - & 0 \\
\hline Enterobacter spp. & 11 & 3.1 & $5(45 \%)$ & $2(18 \%)$ & 0 & - \\
\hline $\begin{array}{l}\text { Corynebacterium } \\
\text { spp. }\end{array}$ & 4 & 1.1 & $1(25 \%)$ & - & - & - \\
\hline Candida albicans & 2 & 0.6 & ND & - & - & - \\
\hline $\begin{array}{l}\text { Achromobacter } \\
\text { spp. }\end{array}$ & 2 & 0.6 & $1(50 \%)$ & - & 0 & - \\
\hline $\begin{array}{l}\text { Stenotrophomonas } \\
\text { maltophilia }\end{array}$ & 2 & 0.6 & 0 & - & 0 & - \\
\hline Providencia stuartii & 2 & 0.6 & 0 & - & 0 & - \\
\hline $\begin{array}{l}\text { Staphylococcus } \\
\text { lugdunensis }\end{array}$ & 1 & 0.3 & 0 & - & - & 0 \\
\hline Alcaligenes faecalis & 1 & 0.3 & $1(100 \%)$ & - & - & - \\
\hline $\begin{array}{l}\text { Morganella } \\
\text { morganii }\end{array}$ & 1 & 0.3 & $1(100 \%)$ & - & 0 & - \\
\hline
\end{tabular}

a Four $P$. aeruginosa had the vim (Verona integron-encoded metallo- $\beta$-lactamase) gene and one A. baumannii produced OXA-23

\section{Discussion}

In this study, from a surgical facility in Africa, Gramnegative rods were the primary aetiology of SSI. Despite differences in ratios between Gram-negative and Grampositive organisms by types of surgery and SSI types, Gram-negatives dominated in all categories. There was a high level of MDR among isolated organisms, including carbapenem-resistant $P$. aeruginosa and $A$. baumannii and ESBL-producing E. coli and K. pneumoniae. There was no phenotypic indication of clonality of the MDR organisms, indicating that the findings could not be explained by an outbreak. These findings challenge the standard recommendations for empiric prevention and treatment of SSI in low- and middle-income countries.

Unlike earlier studies in Ghana, which recorded low rates of microbiology testing [9], this study recorded a high rate of testing. This can be explained by the fact that under the active study conditions, wound swab samples were taken by the surveillance team when an SSI was diagnosed, irrespective of the clinicians' diagnosis, and the cost of the testing was also borne by the study. In low- and middle-income countries, low rates of microbiology testing are often reported, presumably due to the limited facilities for microbiology testing, the costs of testing, limited numbers of trained personnel, and the tendency for clinicians to underutilize existing microbiology facilities $[9,15-18]$ As reported previously, the active surveillance and access to microbiological testing in this study lead to immediate improvements in SSI rates in the course of the study [3].

$E$. coli was the commonest isolated organism, whereas, $S$. aureus and coagulase negative staphylococci constituted less than a fifth of the isolates. Some studies have also predominantly isolated $E$. coli from infected surgical sites post abdominal surgeries $[19,20]$ but in most studies in Africa, S. aureus was the most common pathogen isolated from SSI [21]. The large numbers of gastrointestinal surgeries performed in this study cannot fully explain the predominance of E. coli since Gram-negative rods were the predominant aetiology of SSI in all forms of surgery. A possible explanation of this could be a high rate of skin carriage of Gram-negative organisms as 


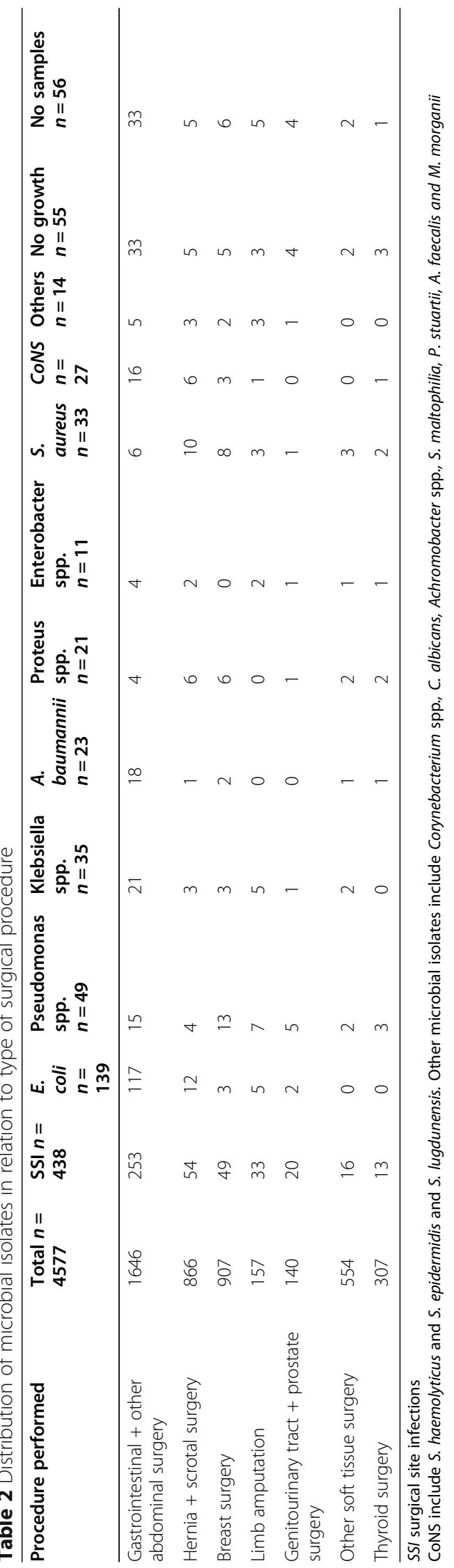


Table 3 Comparison of distribution of Gram negative: Gram positive for type of procedure performed and type of SSI

\begin{tabular}{|c|c|c|c|c|c|c|c|}
\hline $\begin{array}{l}\text { Clinical } \\
\text { characteristics }\end{array}$ & $\begin{array}{l}\text { Total number } \\
\text { of positive } \\
\text { cultures } \\
n=352\end{array}$ & $\begin{array}{l}\text { Total number of } \\
\text { Gram-negative } \\
\text { organisms } \\
n=286\end{array}$ & $\begin{array}{l}\text { Gram- } \\
\text { negative } \\
\text { organisms } \\
\%\end{array}$ & $\begin{array}{l}\text { Total number of } \\
\text { Staphylococcus } \\
\text { spp.(60) } \\
+ \text { other Gram- } \\
\text { positive organ- } \\
\text { isms (4) } \\
n=64\end{array}$ & $\begin{array}{l}\text { Staphylococcus } \\
\text { spp. } \\
+ \text { Other Gram- } \\
\text { positive } \\
\text { organisms } \\
\%\end{array}$ & $\begin{array}{l}\text { Total number of } \\
\text { other microbial } \\
\text { isolates (fungi) } \\
n=2\end{array}$ & $\begin{array}{l}\text { Other } \\
\text { microbial } \\
\text { isolates } \\
\text { (fungi) } \\
\%\end{array}$ \\
\hline \multicolumn{8}{|l|}{ Procedure performed } \\
\hline $\begin{array}{l}\text { Gastrointestinal } \\
+ \text { other } \\
\text { abdominal } \\
\text { surgery }\end{array}$ & 207 & 181 & 87.4 & 24 & 11.6 & 2 & 1.0 \\
\hline $\begin{array}{l}\text { Hernia + scrotal } \\
\text { surgery }\end{array}$ & 47 & 31 & 65.9 & 16 & 34.0 & 0 & 0.0 \\
\hline Breast surgery & 40 & 29 & 72.5 & 11 & 27.5 & 0 & 0.0 \\
\hline $\begin{array}{l}\text { Limb } \\
\text { amputation }\end{array}$ & 26 & 21 & 80.8 & 5 & 19.2 & 0 & 0.0 \\
\hline $\begin{array}{l}\text { Genitourinary } \\
\text { tract + prostate } \\
\text { surgery }\end{array}$ & 12 & 10 & 83.3 & 2 & 16.7 & 0 & 0.0 \\
\hline $\begin{array}{l}\text { Other soft tissue } \\
\text { surgery }\end{array}$ & 10 & 7 & 70.0 & 3 & 30.0 & 0 & 0.0 \\
\hline Thyroid surgery & 10 & 7 & 70.0 & 3 & 30.0 & 0 & 0.0 \\
\hline \multicolumn{8}{|l|}{ Type of SSI } \\
\hline Superficial & 291 & 228 & 78.3 & 61 & 21.0 & 2 & 0.7 \\
\hline Deep & 34 & 31 & 85.3 & 3 & 8.8 & 0 & 0.0 \\
\hline Organ space & 27 & 27 & 100.0 & 0 & 0.0 & 0 & 0.0 \\
\hline
\end{tabular}

shown in a study from Tanzania [22]. In addition, the routine use of antibiotic prophylaxis with an effect on $S$. aureus in our department coupled with a relatively low rate of methicillin resistance may also have skewed the distribution of microorganisms toward Gram negatives. Finally we recently found high levels of antimicrobial air contamination in our surgical facility and demonstrated a causal relationship with SSI [23]. This study indicated that air contamination may have contributed to infections with environmental bacteria such as $P$. aeruginosa and $A$. baumannii, whereas enterobacterales were uncommon in the air samples.
Skin carriage of Gram-negative organisms may be associated with previous antibiotic use. In line with this, it is likely our patients had received antibiotic therapy at referring facilities before coming to our tertiary hospital, where the treatment may have been continued. We have recently documented long periods of administration of antibiotics in surgical units in Ghana, at all levels of health facilities [9]. Long periods of administration of antibiotics have also been reported in other health facilities in low- and middle-income countries [24, 25].

The high usage of antibiotics coupled with the low rate of microbiology testing to inform choice of antibiotic

Table 4 Distribution of microbial isolates in relation to type of surgical site infection (SSI)

\begin{tabular}{|c|c|c|c|c|c|c|c|c|c|c|c|c|}
\hline $\begin{array}{l}\text { Type of } \\
\text { SSI }\end{array}$ & $\begin{array}{l}\text { Number } \\
\text { with surgical } \\
\text { site } \\
\text { infections }\end{array}$ & $\begin{array}{l}E . \\
\text { coli } \\
n= \\
139\end{array}$ & $\begin{array}{l}\text { Pseudomonas } \\
\text { spp. } \\
n=49\end{array}$ & $\begin{array}{l}\text { Klebsiella } \\
\text { spp. } \\
n=35\end{array}$ & $\begin{array}{l}\text { A. } \\
\text { baumannii } \\
n=23\end{array}$ & $\begin{array}{l}\text { Proteus } \\
\text { spp. } \\
n=21\end{array}$ & $\begin{array}{l}\text { Enterobacter } \\
\text { spp. } \\
n=11\end{array}$ & $\begin{array}{l}\text { S. } \\
\text { aureus } \\
n=33\end{array}$ & $\begin{array}{l}\text { CoNS } \\
n= \\
27\end{array}$ & $\begin{array}{l}\text { Others } \\
n=14\end{array}$ & $\begin{array}{l}\text { No } \\
\text { growth } \\
n=55\end{array}$ & $\begin{array}{l}\text { No } \\
\text { samples } \\
n=56\end{array}$ \\
\hline $\begin{array}{l}\text { Superficial } \\
\text { SSI }\end{array}$ & $366(\%)$ & $\begin{array}{l}105 \\
(29 \%)\end{array}$ & 42 (11\%) & $29(8 \%)$ & $18(5 \%)$ & $18(5 \%)$ & $10(3 \%)$ & $\begin{array}{l}33 \\
(9 \%)\end{array}$ & $\begin{array}{l}24 \\
(6 \%)\end{array}$ & $\begin{array}{l}12 \\
(3 \%)\end{array}$ & $\begin{array}{l}45 \\
(12 \%)\end{array}$ & 30 (8\%) \\
\hline Deep SSI & 49 (\%) & $\begin{array}{l}17 \\
(34 \%)\end{array}$ & $3(6 \%)$ & $2(4 \%)$ & $4(8 \%)$ & $2(4 \%)$ & $1(2 \%)$ & 0 & $\begin{array}{l}3 \\
(6 \%)\end{array}$ & $2(4 \%)$ & 7 (14\%) & $8(16 \%)$ \\
\hline $\begin{array}{l}\text { Organ- } \\
\text { space SSI }\end{array}$ & $48(\%)$ & $\begin{array}{l}17 \\
(35 \%)\end{array}$ & $4(8 \%)$ & $4(8 \%)$ & 1 (2\%) & $1(2 \%)$ & 0 & 0 & 0 & 0 & $3(6 \%)$ & $18(37 \%)$ \\
\hline
\end{tabular}

CoNS include S. haemolyticus and S. epidermidis and S. lugdunensis. Other microbial isolates include Corynebacterium spp., C. albicans, Achromobacter spp., S. maltophilia, P. stuartii, A. faecalis and M. morganii 


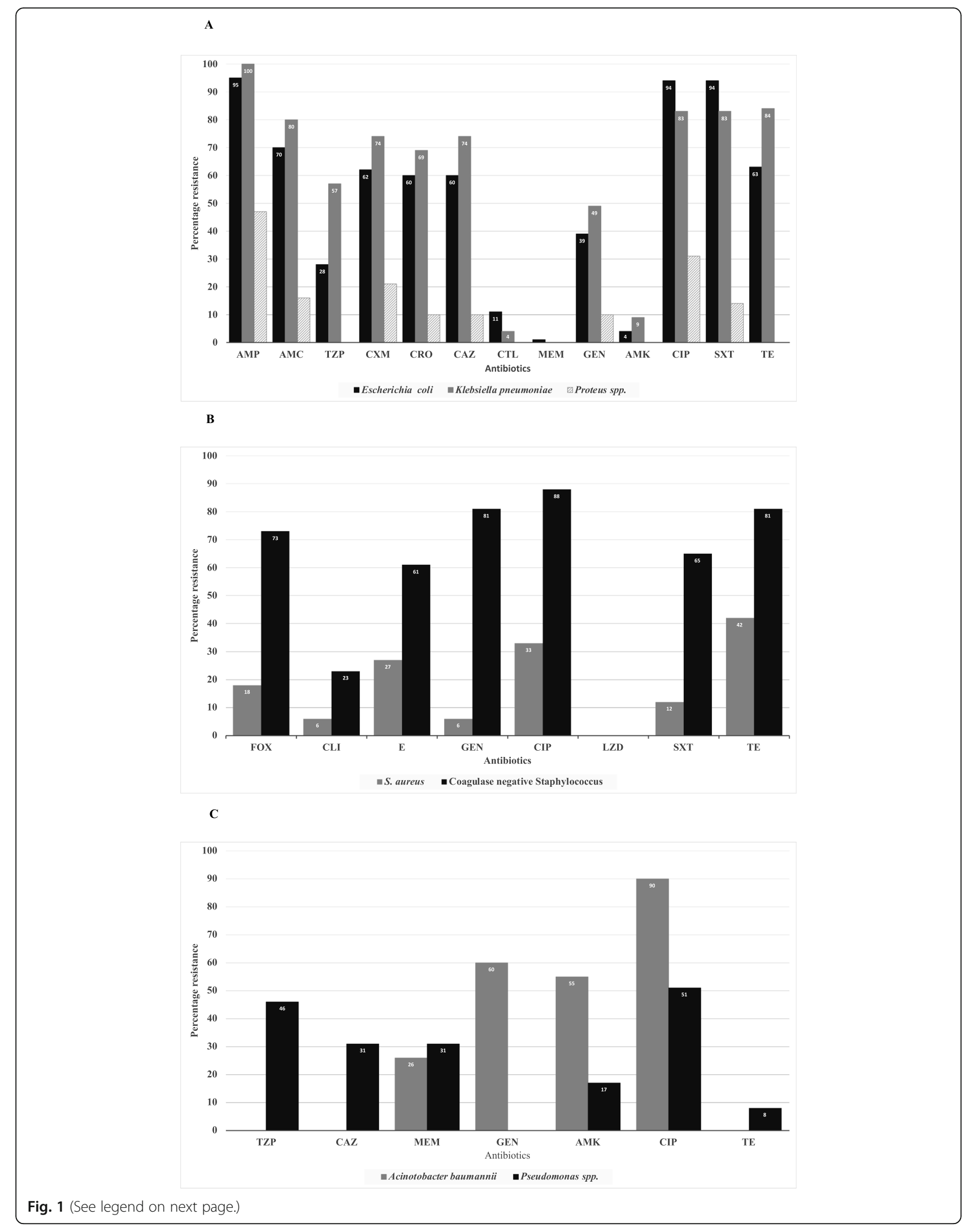


(See figure on previous page.)

Fig. 1 Antibiotic resistance pattern for bacteria isolated from infected surgical sites. a, Eschericia coli, Klebsiella spp. and Proteus spp., b, Pseudomonas aeruginosa and Acinetobacter baumannii, c. Staphylococcus spp. AMC - amoxicillin/clavulanic acid, AMK - amikacin, AMP ampicillin, CAZ - ceftazidime, CIP - ciprofloxacin, CLI - clindamycin, CRO - ceftriazone, CTL - cefotaxime + clavulanic acid, CXM - cefuroxime, E erythromycin, FOX - cefoxitin, GEN - gentamycin, LZD - linezolid, MEM - meropenem, SXT - trimethoprim-sulphamethoxazole, TE - tetracycline, TZP - piperacillin/tazobactam

therapy, may explain the high levels of MDR. Hospitalbased antimicrobial stewardship programs are said to decrease antibiotic use, though data on this is limited in low- and middle-income countries [26]. There is a need to develop and document the effect of functioning antibiotic stewardship programs based on longitudinal monitoring of microbiological test results from the surgical department.

The choice of antibiotics in the department is essentially based on the Ghana standard treatment guidelines, usually reviewed at intervals of 5 years or more [27, 28].

Antibiotics like ciprofloxacin are used routinely by surgeons as therapeutic and prophylactic treatment for gastrointestinal surgery, and in combination with clindamycin for limb amputation for dry and wet lower limb gangrene. The high prevalence of ciprofloxacin resistance in this study, ranging between 95 and 33\% among $E$. coli and $S$. aureus respectively, shows the evolving pattern of resistance. In comparison, a 10\% resistance to ciprofloxacin in fecal E. coli has been reported in the past [29]. Conversely, the low resistance to vancomycin, piperacillin/tazobactam and linezolid may reflect their low usage or unavailability in most Ghanaian facilities, based on the essential medicines list of the ministry of health [27].

The low prevalence of MRSA confirms previous findings from inpatients in our institution [30]. A high use of amoxicillin/clavulanic acid may explain the low frequency of $S$. aureus in our study, but the high prevalence of amoxicillin/clavulanic acid-resistant Gram-negative organisms suggests the need to re-evaluate the protocols.

The resistance to 3rd generation cephalosporins by $K$. pneumoniae and E. coli in our study was mainly caused by ESBL. This cannot be explained by a high usage of third generation cephalosporins as the Ghana treatment guidelines do not recommend this drug class. We have recently reported clonal outbreaks of MDR K. pneumoniae in neonatal intensive care units in Ghana [31], but in the present study we did not find indication of ongoing outbreaks, based on phenotypic analysis. The high ESBL rate may thus mimic antibiotic resistance in patients' own flora indicating widespread carriage of resistant organisms in the society [32].

This study involves data from only one hospital, limiting the generalization of the results, though the hospital serves as a major referral center for a population of over 30 million.

\section{Conclusion}

Gram-negative organisms with a high level of MDR were the predominant organisms isolated from SSI. Antibiotic treatment protocols including prophylactic strategies need to be re-evaluated to improve outcomes and minimize the emergence of antimicrobial resistance.

\section{Abbreviations}

CDC: Centers for Disease Control and Prevention; Corp.: Corporation; ESBL: Extended spectrum beta lactamases; HCAl: Healthcare associated infections; KBTH: Korle Bu Teaching Hospital; MDR: Multidrug resistant; MRSA: Methicillin resistant Staphylococcus aureus; SSI: Surgical site infections; Tx:: Texas; UK: United Kingdom; USA: United State of America

\section{Acknowledgements}

We thank all the interns and nurses of the surgical department involved in taking wound swabs for microbiology analysis, Amos Akumwena of the department of Medical Microbiology of the University of Ghana Medical School, who did all the microbiology identification and susceptibility of isolates for clinical management in Ghana and Sonja Lekovic of the department of Microbiology, Copenhagen University hospital for the confirmation and analysis of the isolates.

\section{Authors' contributions}

$A B B, J A L K, K M, A K L, E O$, and MJN conceptualized the study; participated in its design, coordination and helped to draft the manuscript. ABB collected data and performed the statistical analysis with help of KM. JALK and AKL contributed to microbiological testing. The manuscript was revised for intellectual content by KM, JALK and MJN. All authors have read and approved the final manuscript for submission.

\section{Funding}

This work was supported by DANIDA through the HAI-GHANA PROJECT, [grant number 16-PO1-GHA]. The funder had no role in study design, data collection, analysis and preparation of this manuscript.

\section{Availability of data and materials}

Data is available from corresponding author upon request.

\section{Ethics approval and consent to participate}

Ethical approval was granted by the Korle Bu Teaching Hospital Institutional Review Board, KBTH-STC/RB/00022/2017 and the College of Health Sciences' Ethical and Protocol review committee, CHS-Et/M.8-P4.5/2016-2017. All patients gave a written, informed consent.

\section{Consent for publication \\ Not applicable.}

\section{Competing interests}

None declared.

\section{Author details}

'Department of Surgery, University of Ghana Medical School, University of Ghana, P. O. Box 4356, Accra, Ghana. ${ }^{2}$ Department of Surgery, Korle Bu Teaching Hospital, Accra, Ghana. ${ }^{3}$ Department of Veterinary and Animal Science, University of Copenhagen, Copenhagen, Denmark. ${ }^{4}$ Division of Infectious Disease Preparedness, Statens Serum Institut, Copenhagen, Denmark. ${ }^{5}$ Centre for Medical Parasitology at Department of Immunology and Microbiology, University of Copenhagen, Copenhagen, Denmark. ${ }^{6}$ Department of Clinical Microbiology, Copenhagen University Hospital 
(Rigshospitalet), Copenhagen, Denmark. ${ }^{7}$ Department of Microbiology, Korle-Bu Teaching Hospital, P.O. Box 77, Accra, Ghana. ${ }^{8}$ Department of Medical Laboratory Sciences, School of Biomedical and Allied Health Science, University of Ghana, Legon, Accra, Ghana. ${ }^{9}$ Department of Medical Microbiology, University of Ghana Medical School, University of Ghana, Accra, Ghana.

Received: 14 August 2020 Accepted: 18 November 2020

\section{Published online: 25 November 2020}

\section{References}

1. Nejad SB, Allegranzi B, Syed SB, Ellis B, Pittet D. Health-care-associated infection in Africa: a systematic review. Bull World Heal Organ. 2011;89:757-65.

2. Labi A, Obeng-nkrumah N, Owusu E, Bjerrum S. Multi-Centre pointprevalence survey of hospital- acquired infections in Ghana. J Hosp Infect. 2019;101 (1):60-8. https://doi.org/10.1016/j.jhin.2018.04.019.

3. Bediako-Bowan A, Owusu E, Debrah S, Kjerulf A, Newman MJ, Kurtzhals JAL, et al. Surveillance of surgical site infection in a teaching hospital in Ghana: a prospective cohort study. J Hosp Infect. 2020;104(3):321-7. https://doi.org/ 10.1016/j.jhin.2020.01.004.

4. Fenny AP, Asante FA, Otieku E, Bediako-Bowan A, Enemark U. Attributable cost and extra length of stay of surgical site infection at a Ghanaian teaching hospital. Infect Prev Pract. 2020;2(2):100045. https://doi.org/10. 1016/j.infpip.2020.100045.

5. Ayukekbong JA, Ntemgwa M, Atabe AN. The threat of antimicrobial resistance in developing countries: Causes and control strategies. Antimicrob Resist Infect Control. 2017;6 Available from: https://aricjournal.biomedcentral.com/track/ pdf/10.1186/s13756-017-0208-x. [cited 2018 Sep 19].

6. Atif M, Scahill S, Azeem M, Sarwar MR, Babar ZUD. Drug utilization patterns in the global context: a systematic review. Heal Policy Technol. 2017;6(4): 457-70. https://doi.org/10.1016/j.hlpt.2017.11.001.

7. Machowska A, Sparrentoft J, Dhakaita SK, StålsbyLundborg C, Sharma M. Perioperative antibiotic prescribing in surgery departments of two private sector hospitals in Madhya Pradesh, India. Perioper Med. 2019;8(1):1-12.

8. Byarugaba DK. Antimicrobial resistance in developing countries and responsible risk factors. Int J Antimicrob Agents. 2004;24:105-10.

9. Bediako-Bowan AAA, Owusu E, Labi AK, Obeng-Nkrumah N, Sunkwa-Mills G, Bjerrum S, et al. Antibiotic use in surgical units of selected hospitals in Ghana: a multi-Centre point prevalence survey. BMC Public Health. 2019; 19(1):797-807.

10. Center for Disease Prevention and Control. National Healthcare Safety Network (NHSN) Procedure-associated Module SSI. Surgical Site Infection (SSI ) Event.2020. Available from: http://www.cdc.gov/nhsn/PDFs/ pscManual/9pscSSIcurrent.pdf.

11. European Committee on Antimicrobial Susceptibility Testing Breakpoint tables for interpretation of MICs and zone diameters European Committee on Antimicrobial Susceptibility Testing Breakpoint tables for interpretation of MICs and zone diameters. Version 10. http://www.eucast.org. 2020. 0-77 p. Available from: http://www.eucast.org/fileadmin/src/media/PDFs/ EUCAST_files/Breakpoint_tables/v_5.0_Breakpoint_Table_01.pdf. Accessed on 5 Aug 2020.

12. European Committee on Antimicrobial Susceptibility Testing. EUCAST: Clinical breakpoints and dosing of antibiotics V 10.0. 2020. Available from: https://www.eucast.org/clinical_breakpoints/. [cited 2020 Nov 5].

13. European committee on antimicrobial susceptibility testing. EUCAST guidelines for detection of resistance mechanisms and specific resistances of clinical and/or epidemiological importance. 2017.

14. Magiorakos AP, Srinivasan A, Carey RB, Carmeli Y, Falagas ME, Giske CG, et al. Multidrug-resistant, extensively drug-resistant and pandrug-resistant bacteria: an international expert proposal for interim standard definitions for acquired resistance. Clin Microbiol Infect. 2012;18(3):268-81. https://doi.org/ 10.1111/j.1469-0691.2011.03570.x.

15. Petti CA, Polage CR, Quinn TC, Ronald AR, Sande MA. Laboratory medicine in Africa: a barrier to effective health care. Clin Infect Dis. 2006:42(3):377-82.

16. Labi AK, Obeng-Nkrumah N, Owusu E, Bjerrum S, Bediako-Bowan A, Sunkwa-Mills G, et al. Multi-centre point-prevalence survey of hospitalacquired infections in Ghana. J Hosp Infect. 2019;101(1):60-8 Available from: https://linkinghub.elsevier.com/retrieve/pii/S0195670118302573. [cited 2018 Dec 21].

17. Barbé B, Yansouni CPP, Affolabi D, Jacobs J. Implementation of quality management for clinical bacteriology in low-resource settings. Clin
Microbiol Infect. 2017;23(7):426-33 Available from: http://linkinghub.elsevier. com/retrieve/pii/S1198743X17302628. [cited 2018 Aug 5].

18. Polage CR, Bedu-Addo G, Owusu-Ofori A, Frimpong E, Lloyd W, Zurcher E, et al. Laboratory use in Ghana: Physician perception and practice. Am J Trop Med Hyg. 2006;75(3):526-31 Available from: https://www.scopus.com/ record/display.uri?eid=2-s2.0-33750577019\&origin=inward\&txGid=5aa885 d8f1c91b27b9780b197861b6ab. [cited 2018 Aug 5].

19. Alkaaki A, Al-Radi OO, Khoja A, Alnawawi A, Alnawawi A, Maghrabi A, et al. Surgical site infection following abdominal surgery: a prospective cohort study. Can J Surg. 2019;62(2):111-7.

20. Du M, Liu B, Li M, Cao J, Liu D, Wang Z, et al. Multicenter surveillance study of surgical site infection and its risk factors in radical resection of colon or rectal carcinoma. BMC Infect Dis. 2019;19(1):1-6.

21. Sisay M, Worku T, Edessa D. Microbial epidemiology and antimicrobial resistance patterns of wound infection in Ethiopia: a meta-analysis of laboratory-based cross-sectional studies. BMC Pharmacol Toxicol. 2019;20(1):1-19.

22. Moremi N, Claus H, Rutta L, Frosch M, Vogel U, Mshana SE. High carriage rate of extended-spectrum beta-lactamase-producing Enterobacteriaceae among patients admitted for surgery in Tanzanian hospitals with a low rate of endogenous surgical site infections. J Hosp Infect. 2018;100(1):47-53. https://doi.org/10.1016/j.jhin.2018.05.017.

23. Stauning MA, Bediako-Bowan A, Bjerrum S, Andersen LP, Andreu-Sánchez $S$, Labi AK, et al. Genetic relationship between bacteria isolated from intraoperative air samples and surgical site infections at a major teaching hospital in Ghana. J Hosp Infect. 2020;104(3):309-20.

24. Talaat M, Saied T, Kandeel A, El-ata GAA, El-kholy A, Hafez S, et al. A point prevalence survey of antibiotic use in 18 hospitals in Egypt. Antibiotics. 2014;3:450-60.

25. Wattal C, Khanna S, Goel N, Oberoi JK, Rao BK. Antimicrobial prescribing patterns of surgical speciality in a tertiary care hospital in India: Role of persuasive intervention for changing antibiotic prescription behaviour. Indian J Med Microbiol. 2017;35(3):369-75 Available from: http://www.ncbi. nlm.nih.gov/pubmed/29063881. [cited 2018 Jul 5].

26. Nathwani D, Varghese D, Stephens J, Ansari W, Martin S, Charbonneau C. Value of hospital antimicrobial stewardship programs [ASPs]: a systematic review. Antimicrob Resist Infect Control. 2019;8(1):1-13.

27. Ministry of Health. Standerd Treatment Guidelines. 7th ed. Standard Treatment Guidelines. Accra: Ghana National Drugs Programme (GNDP) Ministry of Health; 2017. p. 1-1416.

28. Koduah A, Asare BA, Gavor E, Gyansa-Lutterodt M, Andrews Annan E, Ofei FW. Use of evidence and negotiation in the review of national standard treatment guidelines and essential medicines list: experience from Ghana. Health Policy Plan. 2019;34:II104-20.

29. Namboodiri SS, Opintan JA, Lijek RS, Newman MJ, Okeke IN. Quinolone resistance in Escherichia coli from Accra, Ghana. BMC Microbiol. 2011;11.

30. Egyir B, Guardabassi L, Nielsen SS, Larsen J, Addo KK, Newman MJ, et al. Prevalence of nasal carriage and diversity of Staphylococcus aureus among inpatients and hospital staff at Korle Bu teaching hospital, Ghana. J Glob Antimicrob Resist. 2013;1 (4):189-93. https://doi.org/10.1016/j.jgar.2013.05.006.

31. Labi A-K, Nielson K, Marvig R, Bjerrum S, Enweronu-Laryea C, Bennedbæk M, et al. Outbreak of carbapenemase producing Klebsiella pneumoniae in a neonatal intensive care unit in Ghana. Emerg Infect Dis. 2020; 26(9):2235-8.

32. Obeng-Nkrumah N, Molecular epidemiology of beta-lactamase producing Escherichia coli and Klebsiella pneumoniae in Ghana. Doctoral dissertation, University of Ghana; 2016.

\section{Publisher's Note}

Springer Nature remains neutral with regard to jurisdictional claims in published maps and institutional affiliations. 